\title{
Against Limits: A Post-Structural Theorizing of Resistance in Leisure
}

Erin Sharpe, Brock University

Resistance has always been a slippery concept to study. What, exactly, is resistance? How do we know it when we see it? And who gets to decide? As Weitz (2001, p. 669) wrote, the term resistance "remains loosely defined, allowing some scholars to see it almost everywhere and others almost nowhere." In a review of the sociological literature, Hollander and Einwohner (2004) found that while the term is often used, scholars fail to define it in any systematic way, and noted that "everything from revolutions to hairstyles has been described as resistance" ( $p$. 534). Perhaps this argument could be applied to leisure studies as well, where resistance has been linked to a wide range of leisure practices, spaces, and identities including young girls' leisure-based smoking (Wearing, 1998), older adults gardening (Raisborough and Bhatti, 2007), parkour (Bavinton, 2007), roller derby (Pavlidis, 2013), female Harley riders (Roster, 2007), and competitive masters athletes (Dionigi, 2002). Sharp, Routledge, Philo, and Paddison (2000) expressed concerns that the concept has become so widely applied that it has become almost meaningless. Perhaps this is why some of the recent research on politically-charged leisure draws on theoretical frameworks or concepts other than resistance, such as queer theory (Calley-Jones, 2010), "anarcho-politics" (Gilchrist and Ravenscroft, 2013), and prefigurative politics (CalleyJones and Mair, 2014; Sharpe, 2008). Given this breadth and variety of its conceptualization, is resistance still relevant? 
In this chapter I argue that resistance is still relevant to leisure studies. The field came to an interest in resistance through its recognition that leisure is not "innocent" but, like any domain, is a sphere of struggle in which power is negotiated, won, and lost (Shaw, 2001). Studying resistance allows us to look more closely at the various contestations and power struggles that play out in and through leisure, and the ways that leisure is used to oppose or change various manifestations of domination and the status quo. And, in its recognition of oppositional behaviour as informed and political, resistance offers us a way to explore the interconnections between leisure and politics in meaningful ways (Raby, 2005). That said, resistance is not resistance is not resistance - how we think of resistance is shaped by how we think of power (Raby, 2005; Shaw, 2001). For the concept to have utility for theorizing interconnections between leisure and politics, it needs to be located within broader theorizations of power.

To this end, this chapter offers readers a post-structural theorizing of resistance in leisure. Not all scholarship on resistance in leisure has been undertaken from a post-structural vantage point; in fact, much if not the majority of research has looked at resistance in leisure through a modernist lens that conceptualizes resistance in terms of acts of opposition, conducted by subordinate groups against a dominant power. I begin the chapter with a review of modernist perspectives and offer some illustrations of leisure research and practice that have been undertaken within this theoretical position. Following this, I offer post-structural theorizations of power and resistance. The contents of this section draw almost exclusively on the work of Foucault, therefore I acknowledge that what is being offered as post-structuralism is more accurately, a Foucauldian theorization of power. Foucault conceptualized power as circulating through a culture or a system and exercised at innumerable points and times. Power is not held 
but exercised, and arguably in Foucault's framework (and indeed the argument has been made) power and resistance are, ontologically, redundant concepts. Interestingly, even in acknowledging this redundancy, Foucault continued to apply the concept of resistance in his work because, as I explain in the third section of the chapter, the concept of resistance gave Foucault a language to promote his politics. Politically, Foucault promoted freedom; what he was against, and thus resisted, were any limits or constrictions placed on the possibilities for how people might wish to live their lives. To Foucault, resistance was power exercised in the attempt to destabilize the limits of the present order, including what we do, what we know as truth, and our sense of who we are (Hoy, 2004). In the last section of chapter, I apply Foucault's perspective of resistance as "against limits" to leisure research and practice.

\section{Modernist Perspectives on Power and Resistance}

Foucault's conceptualization of power ran counter to the dominant social theories of the time, which framed power in terms of a binary of dominance and subordination. In these "orthodox" (Sharp et al., 2000) or "modernist" (Raby, 2005) perspectives, power was equated with domination: the power to coerce or to control. Dominant groups 'held' power and wielded it against a subordinate; subordinates, in turn, resisted and attempted to 'seize' power (Raby, 2005). Modernist scholars of power had varying interests regarding who dominated and which power structures to attend to. Marxist and subcultural theorists, for example, focused on power embedded in class structure, whereas feminist scholars focused on how power was embedded in patriarchies (Raby, 2005). 
Modernist theoretical perspectives conceptualize resistance as having two core elements: action and opposition (Hollander and Einwohner, 2004). In other words, resistance is an activity: it is "a social action that is carried out in some kind of oppositional relation to power" (Johansson and Vinthagen, 2015, p. 109). Over time, the concept of resistance has expanded, to include not only direct, open, and confrontational acts of resistance such as protests and strikes but also the less visible and everyday acts of opposition such as foot-dragging, feigned ignorance, or sabotage. James Scott, resistance scholar and author of Domination and the Arts of Resistance was influential in this regard. Scott's work focused on the resistance of peasant peoples to various systems of domination (e.g., political, economic, cultural, religious). In this work he was able to show the varied ways that a subordinate group might resist when open confrontation and direct action are not easily available. He showed how the acts of resistance of peasant groups were more disguised, piecemeal, quiet, and "every day" forms of resistance. For Scott, resistance is "any act(s) by member(s) of a subordinate class that is or are intended either to mitigate or deny claims made on that class by superordinate classes or to advance its own claims vis-à-vis those super-ordinate classes" (1989, p. 36).

Modernist perspectives on resistance in leisure maintain this binary of dominant and subordinate. From this theoretical vantage point leisure is conceptualized as a political arena that is used either by dominant groups in ways that extend or maintain the "established order" or by subordinate groups to oppose or challenge it (Carrington, 1998, p. 279). Oppositional action in and through leisure may take a variety of forms - it may be collective or individual, public or private, symbolic or material. The scholarly literature offers many examples of subordinate groups using various forms of leisure to oppose or challenge the 'established order;' excellent 
examples include Radway's (1991) analysis of women claiming leisure time to read romance novels in an effort to resist patriarchy, Wallace and Alt's (2001) report of the 1930s German youth swing dancing movement as an act of opposition to the Nazi totalitarian regime, and Beal's (1995) analysis of skateboarding as resistance to capitalist ideology.

Perhaps nowhere in the field of leisure is this perspective considered more than in the arena of sport. As Messner (1992) argued, "sport must be viewed as an institution through which domination is not only imposed, but also contested; an institution in which power is constantly at play" (p. 13). As sport scholars have noted, sport can become transformed into vehicles for political or cultural resistance, particularly when sporting contests involve subordinate (e.g., colonized, racialized, politically oppressed) groups playing against groups that represent the dominant power. By way of example, much of the scholarly attention that has been directed to analyzing the sport of cricket has focused on cultural or political resistance. Due to the history of cricket in relation to British imperialism, cricket contests that involve nations or peoples that have been dominated through the history of British colonization (e.g., West Indies (James, 1963), India (Khondker, 2010), and Black British (Carrington, 1998)) cricket matches become opportunities to symbolically resist domination and express national or cultural pride - especially in matches in which the subaltern group "beats them at their own game".

The debates that circulate in relation to modernist conceptualizations of power and resistance focus on issues of intent, analytical perspective, and effects (Raby, 2005). For example, does a "resistor" need to have the intent to resist for the act to "count" as resistance? Or do we focus on the effects of the act, regardless of its intentions? Who decides what qualifies as resistance: the actors or the analyst? Resistance theorists respond differently to these questions. 
Vinthagen and Lilja (2007), for example, argued that a consciousness of intent from the actor is not required; intent does not matter as long as the action involved an act done by someone subordinate, that in response to power challenges power, and that the act contains at least a possibility that power gets undermined by the act. Alternatively, intent is important to Routledge (1997), who defined resistance as "any action imbued with intent that attempts to challenge, change, or retain particular circumstances relating to social relations, processes, and/or institutions" (p. 361).

Questions are also raised regarding the ways that modernist theories of resistance are built on, and maintain, certain theoretical assumptions about social structure, agency, and the subject. In modernist theorizing, resistance is the result of agency arising from a rational, prediscursive, internally coherent, acting subject (MacDonald, 1991). As Raby (2005, p. 161) pointed out, in modernist theories of power "the subject is whole, with a clear position in relation to domination, rather than fragmented, and thus has a clear source of agency, and of morality". From this position, the avenues for social change, such as overthrowing the dominating class, while daunting, are clear as it is evident who is dominant and who is subjugated. Raby (2005) wondered if these aspects of modernist theories of resistance are part of what make them attractive: the enemies are easy to spot and the avenues for social change are more clear-cut. However, as Rose (2002) noted, modernist resistance theory is also caught in a trap: that "by illustrating the different ways that agents respond to dominant power, [it] inadvertently establishes the system as a pre-established entity" (p. 383). And resistance may be more fragmented and transitory than can be accounted for in and through the modernist narrative. 


\section{Foucauldian Perspective on Power and Resistance}

A Foucauldian perspective on resistance is altogether different from modernist perspectives on resistance because Foucault conceived of power altogether differently. Foucault rejected a number of the fundamental principles of modernist theorizing of power, including the notion that power equated to domination. Rather than viewing power as a "thing" - a possession that could be "acquired, seized, or shared" (1990, p. 94), Foucault conceived of power as an ability that was produced and exercised in the myriad social relations in which we are all embedded. It was, put simply, "the ability of individuals to create change, no matter how insignificant" (Heller, 1996, p. 83). In Foucault's conceptualization of social life, power is ubiquitous, diffuse, and omnipresent, moving and circulating through a "capillary-like" network of social relations and “exercised from innumerable points" (1977; 1990, p. 94). As Foucault described:

[Power] is produced from one moment to the next, at every point, or rather in every relation from one point to another. Power is everywhere; not because it embraces everything, but because it comes from everywhere. And 'Power,' insofar as it is permanent, repetitious, inert, and self-reproducing, is simply the over-all effect that emerges from all these mobilities.

(Foucault, 1990, p. 93)

Foucault rejected the modernist conception of power as a binary ("There is no binary and allencompassing opposition between rulers and ruled at the root of power relations" [1990, p. 94]), not because he rejected that unequal power relations exist, but because of how binary theorizing 
presupposes a relationship of domination and submission between groups of people. Foucault argued that the groups that we assume to hold power - governments, social institutions, laws, dominant groups, and the like - are the result, not the cause of workings of power, and represent "only the terminal forms power takes" (p. 92). Foucault was interested in exploring and exposing the workings of power - the ways that power is produced and exercised in the daily and ceaseless relations that occur between all people in all locations of the power network. He wanted to know: How is power exercised in attempts to influence or control the actions of others? How is domination (of individuals, groups, corporations, and states) achieved, and through what strategies or tactics? Further, how is power exercised "from below" - by the so-called "subordinate" individuals or groups in the power relation? For example, how might a student (by not answering a question) exercise power that influences the teacher? How might an athlete (by threatening to quit) influence the coach (Markula and Pringle, 2006)?

Foucault's theory of power has necessarily demanded a re-thinking of the concept of resistance. Whereas in modernist frameworks resistance conceptualized as action coming from 'outside' the power structure (and directed toward the inside), Foucault contended that "resistance is never in a position of exteriority in relation to power...there is no "escaping" it, there is no absolute outside...this would be to misunderstand the strictly relational character of power relationships" (1990, p. 95). Foucault promoted a vision of power and resistance as much more entangled, existing in a relation akin to a yin-yang (Sharp et al., 2000). Indeed, as his oftenquoted phrase "where there is power, there is resistance" (Foucault, 1990, p. 95) suggests, there is no complete separation between enactments of power and resistance; "one will always contain at least the seed of the other" (Sharp et al., 2000, p. 20). Resistance tends to be conceptualized 
as mobile and transitory; rather than 'violent ruptures' that overturn power, there are "cleavages" - points, knots, or focuses of resistance - that are distributed in irregular fashion over power relations at multiple points (Foucault, 1990).

Because Foucault (1990) emphasized the existence of a multiplicity of points of power and resistance in a power network and further, that each point of resistance is a special case deserving of its own consideration and analysis, a Foucauldian perspective pushes us toward an analytical approach that focuses on the micro-workings of power: the ways that power is exerted and contested in the daily, mundane relations and interactions that comprise social life. And, we can see this interest in the micro-workings of power and the exercise power "from below" in the scholarship on leisure undertaken using a post-structural perspective. What is emphasized in these works are the unique and local context, a multiplicity of relations of power, and the ways that power is both enacted and resisted.

For example, a paper by Raisborough and Bhatti (2007) about the gardening experiences of a woman named "Joy", offers a useful example of a post-structural analysis of resistance. In their analysis, the authors refused to claim Joy's gardening as resistance to (or reproduction of) domination, as their intent was to unsettle the domination-resistance binary. The authors instead focused on how Joy negotiated through and creatively positioned herself within the traditional gendered norms to which she was subjected (e.g., wife, mother, neighbour, friend, gardener). In so doing, the authors emphasized that while Joy's varied identities were restraining, Joy was also able to manoeuvre through them to "find her own location". Similarly, Pavlidis' (2013) poststructural telling of her experience in roller derby refuses to frame roller derby as "a simple case of women united against a 'dominating' men 'outside' of roller derby" (p. 665). Instead, Pavlidis 
focused the analytical lens on the workings of power among women involved in roller derby and her own desires, strategies, and practices in her attempt to occupy the subject position "roller derby grrl". Pavlidis' analysis also showed how subject positions such as "roller derby grrl" are simultaneously restraining and liberating, in that they celebrate certain versions of femininity while rejecting others.

Similarly, Bavinton (2007) engages in a post-structural reading of the practice of parkour or urban freerunning. Parkour is a way of moving in which runners appropriate and creatively reinterpret various urban forms (buildings, rails, ramps, walls) in their effort to move fluidly and swiftly from point $A$ to point $B$ in an urban space. Parkour as an activity challenges norms of behaviour and the rules of how spatial-material features are to be used. While Bavinton argued that parkour is resistance, he rejected structuralist notions of the resistance in parkour as a struggle against power. Instead, he emphasized how power and resistance are relational and it is the very existence of norms and conventions that enables the exercise of resistance. In the case of parkour, resistance is exercised when runners play with and circumvent the norms of behaviour and conventional uses of public space. Acknowledging that the effects of these acts of resistance are transitory, Bavinton also showed how the effects of power are negotiated and incomplete.

Foucault's theorizing of power as relational has introduced an important question: Are power and resistance redundant concepts? Heller (1996), for example, contended that resistance is an impossibility in Foucault's framework because power and resistance are no more than two different names that Foucault gave to the same capacity. Similarly, Rose (2002) has called resistance a "theoretically redundant" concept because "practices of domination and resistance 
are both enactments... They operate in overlapping networks of enactment and are dedicated to appropriating and reconfiguring each other's efforts" (p. 396). Foucault's framework has led some to wonder if resistance has any theoretical or analytical utility at all. Should Foucault reject resistance? Does he? If the answer to these questions is no, then it begs new ones: Where and what is resistance in Foucauldian theorizing? Why does it remain?

\section{Post-Structural Resistance: Destabilizing Limits}

Foucault did consider power and resistance redundant concepts. However, he did not reject resistance; instead he continued to discuss, theorize, and locate it in his theorizing of the relationships between freedom, power and domination. How do we make sense of this contradiction? It helps to remember that Foucault was a scholar of contradictions. He was both a philosopher and a social scientist, and while Foucault the philosopher saw no ontological distinction between power and resistance, as a social scientist the term offered a useful way of communicating what he was for politically, as well as what he was against. Fundamentally, what Foucault was for was freedom - in other words, an expansion of the possibilities for how we might want to live or lives or be who we want to be. He framed domination and resistance in these terms as well. As Hoy (2004) wrote, Foucault thought that "power can be productive if it opens up new possibilities, but it turns into domination if its function becomes entirely the negative one of shrinking and restricting possibilities" (p. 66).

Foucault's career-long interest in tracing the histories of "systems of thought" - the knowledges and truths that are accepted without question in a particular field - was driven by his concern with power and domination. In most of his work Foucault traced the dynamics of two processes: "freezing and liquefaction - the ways that categories of various sorts are delineated 
and stabilized, and de-delineated and destabilized" (Michael and Stills, 1992, p. 873). Like Nietzsche, Foucault questioned the innocence of our accepted truths; he thought of truth as 'invented' rather than 'discovered' and what emerges as truth is not the result of progressive or continuous development but of power struggles - "accidents, violence, disputes and clashes of will" (Markula and Pringle, 2006, p. 12). The thrust of Foucault's historical work was to trace how particular ideas come to be fixed and elevated as truth and knowledge at particular times and places, while alternatives become rendered invisible or inarticulable (Michael and Stills, 1992).

This work had a political intent as well. Foucault considered systems of thought to be inherently limiting; in fact, that is essentially what a system of thought does: it lays a grid of intelligibility atop of social life that delimits the sayable, intelligible, and visible from the unintelligible and invisible (Sotiropulos, 2013). A system of thought also delimits people: it establishes boundaries and rules for what is recognized and counts as a person - what counts, for example as a proper relation to one's gender, or nationality, sporting practice, or role in the classroom (Markula and Pringle, 2006). In so doing it recognizes, categorizes, constrains, and subjects individuals to certain ends, identities, and modes of behaviour. In other words, the system of thought sets limits to freedom; what is produced as "identity" is fabricated from within the possibilities that are intelligible in the system.

Foucault used the term subjectification to describe the process through which people become categorized within a particular system of thought. He spent much of his career focused on examining the production and effect of systems of thought of the various human sciences, tracing "how knowledge produced in these fields acted to construct humans as particular objects - such as Caucasians, asthmatics, homosexuals or morons... and how humans subsequently 
become subject to those scientific truths" (Markula and Pringle, 2006, pp. 8-9). He was especially concerned with the ways that systems of thought were particularly punishing "for people who behave in specific sorts of ways, who have certain types of habits, who engage in certain kinds of practices, and who put to work specific kinds of institutions" (Foucault, 2001, p. 74). He was amazed that these punishments were generally accepted without question. He wanted to know: Why do people "buy in" to particular regimes of truth? How are people made to accept the power to punish - or when punished, tolerate being so (Hoy, 2004)?

Foucault's turned some of his attention to power that is exercised in ways that maintain particular regimes of truth. He was interested in forms of power that had the ability to discipline - the ability to control, judge, and normalize subjects in such a way that they were "destined to a certain mode of living or dying". He considered norms to be one of the great instruments of power partly because their effects are easily masked; although we use norms to help us make sense of, classify, and judge our different actions and behaviours, they tend to be "unwritten rules" that circulate unremarked yet over time become asserted as not only normal, but also necessary, natural, and universal (Hoy, 2004, p. 66). Foucault was not against norms per se; he was concerned with normalization - the linking of norms to power in ways that encourage people to value and become efficient at performing a narrowly defined set of practices (Taylor, 2006). He was concerned with the expansion of normalizing judgment throughout our social institutions. As he described, "the judges of normality are everywhere...":

We are in the society of the teacher-judge, the doctor-judge, the educator-judge, the social worker-judge; it is on them that the universal reign of the normative is based; and 
each individual, wherever he may find himself, subjects to it his body, his gestures, his behaviour, his aptitudes, his achievements.

(1977, p. 303)

Again, Foucault's concern with norms was with how norms limited possibilities. As Hoy (2004, p. 66) wrote, the problem with normalization is that it has "spread too far in our lives, and is blocking many other viable forms of life. The constriction of possibilities is achieved when normalization asserts the norms as necessary, or natural, or universal."

If we put this all together, we can see where resistance fits in Foucault's political project. What he was really against, as Pickett (1996, p. 466) explained, was limits:

What, then, is resistance against? Foucault's answer is "limits." Foucault is concerned with the foundational issues of a culture. These are basic categories, which he sees as dichotomies, providing the context for social belief and action, such as good/evil and normal/pathological.

Therefore, resistance involves acts against limits - acts of refusal, negation, destabilization, disobedience, or transgression of the limits of the present order, including what we know as truth, what we do, and our sense of who we are.

(Hoy, 2004, p. 94) 


\section{A Post-Structural Resistance in Leisure}

What does Foucault's theory of resistance offer to the study and practice of leisure? For one, it offers some fruitful directions for leisure scholarship, as it encourages a scholarship of problematization: scholarship that calls into question the norms, behaviour, and constructed categories of various leisure-based systems of thought. Clearly, Foucault has shown us that his historical / genealogical scholarship is resistance; genealogy is able to show that the body has lived differently, which allows us to recognize that it "can be seen to be 'more' than what it now has become... the contrast alone will not make us change, of course, but it will open the possibility of change" (Hoy, 2004, p. 63).

A number of scholars of leisure and sport have embarked on important historical work in this regard. For example, Adams' (2011) genealogy of figure skating has revealed shifting gender norms for both men and women; although now associated with femininity, at one-time figure skating had been exclusively a gentlemen's pastime that celebrated masculine grace and style. Adams' study exposes and troubles the association between particular bodily movements and the constructed categories of gender. However, a scholarship of problematization need not only be historical; any research that troubles the taken-for granted truths and assumed knowledges of various leisure-related fields can have destabilizing effects.

A post-structural theory of resistance also offers innumerable possibilities for leisure as everyday lived practice. We can think of leisure practice as resistance when it takes the form of acts of refusal and disruption of the limits that are produced and normalized through everyday action and behaviour. It involves leisure that recognizes things in new ways - as more than they were. Again, Bevinton's (2007) discussion of parkour offers an instructive example. Parkour as a 
leisure practice disrupts some of the spatial-material limits of everyday public space; in so doing, particular features (e.g., the public park bench) become recognized as something more that they were before (a springboard, a tightrope).

It can also involve leisure that recognizes people differently, often involving a dissolution or negation of the subject. Butler (2002) refers to this as a process of "unbecoming subjects". Unbecoming implies an undoing of self and in some extent it is; unbecoming involves problematizing the limits that are placed on 'what a subject can be' and enacting those problematics through acts of disobedience "to the principles by which one is formed" (p. 221). This involves, as Hoy $(2004$, p. 89) described, "dissolving your sense of who you are and disrupting your sense of what the right thing to do is" (Hoy, 2004, p. 89). However, unbecoming is more than this: it is also a practice that opens up spaces for creative possibility. Through negating what is known, we open up possibilities to imagine otherwise and enter a world of "may be". As Markula (2003) described, it is when we can question the 'naturalness' of our identity and recognize ourselves as subjects and with resistant agency that "the possibility of transgression emerges and thus, the potential for creating new types of subjective experiences" (p. 102).

Therefore, we can think of leisure practice as resistance when it allows us the space to try to create ourselves as works of art, and expands the possibilities for who we might imagine ourselves to be. 


\section{References}

Adams, M.L. (2011) Artistic Impressions: Figure Skating, Masculinity, and the Limits of Sport. Toronto: University of Toronto Press.

Beal, B. (1995) Disqualifying the official: An exploration of social resistance through the subculture of skateboarding. Sociology of Sport Journal, 12, pp. 252-267.

Bavinton, N. (2007) From obstacle to opportunity: Parkour, leisure, and the reinterpretation of constraints. Annals of Leisure Research, 10 (3-4), pp. 391-412.

Butler, J. (2002) What is critique? An essay on Foucault's Virtue. In: Ingram, D. ed. The Political: Readings in Continental Philosophy. London: Blackwell.

Calley Jones, C. (2010) Playing at the queer edges. Leisure Studies, 29 (3), pp. 269-287.

Calley Jones, C. and Mair, H. (2014) Magical activism: what happens between the worlds changes the Worlds. Journal of Leisure Research, 17 (3), pp. 296-313.

Carrington, B. (1998) Sport, masculinity, and black cultural resistance. Journal of Sport and Social Issues, 22 (3), pp. 275-298.

Dionigi, R. (2002) Resistance and Empowerment through Leisure: The Meaning of Competitive Sport Participation to Older Adults. Loisir et Société / Society and Leisure, 25 (2), pp. 303-328.

Foucault, M. (1977) Discipline and punish: The birth of the prison. trans. Sheridan, A. New York, NY: Pantheon Books.

Foucault, M. (1990) The History of Sexuality: An Introduction. trans. Hurley, R. London: Penguin Books.

Foucault, M. (2001) Fearless Speech. ed. Pearson, J. Los Angeles, CA: Semiotext(e). 
Gilchrist, P. and Ravenscroft, N. (2013) Space hijacking and the anarcho-politics of leisure. Leisure Studies, 32 (1), pp. 49-68.

Heller, J. (1996) Power, subjectification, and resistance in Foucault. SubStance, 25 (1), pp. 78-110. Hollander, J.A. and Einwohner, R.L. (2004) Conceptualizing resistance. Sociological Forum, 19 (4), pp. 533-554.

Hoy, D.C. (2004) Critical Resistance: From Poststructuralism to Post-Critique. Cambridge, MA: MIT Press.

James, C.L.R. (2013) Beyond a Boundary (50 th Anniversary Edition). Durham, NC: Duke University Press.

Johansson, A. and Vinthagen, S. (2015) Dimensions of everyday resistance: the Palestinian Sumūd. Journal of Political Power, 8 (1), pp. 109-139.

Khondker, (2010) Globalization, cricket, and national belonging. In: Rumford, C. and Wagg, S. eds. Cricket and Globalization. Newcastle-upon-Tyne: Cambridge Scholars, pp. 152-171.

MacDonald, E. (1991) The Trouble with Subjects: Feminism, Marxism and the Questions of Poststructuralism. Studies in Political Economy, 35, pp. 43-71.

Markula, P (2003) The Technologies of the Self: Sport, Feminism, and Foucault. Sociology of Sport Journal, 20, pp. 87-107.

Markula, P., and Pringle, R. (2006) Foucault, Sport and Exercise: Power, Knowledge, and Transformation of the Self. New York, NY: Routledge.

Messner, M. (1992) Power at play: Sports and the problem of masculinity. Boston, MA: Beacon. Michael, M., and Stills, A. (1992) A resource for resistance: Power-knowledge and affordance. Theory and Society, 21, pp. 869-888. 
Pavlidis, A. (2013) Writing resistance in roller derby. Journal of Leisure Research, 45 (5), pp. 661676.

Pickett, B.L. (1996) Foucault and the politics of resistance. Polity, 28 (4), pp. 445-466.

Raisborough, J., and Bhatti, M. (2007) Women's Leisure and Auto/Biography: Empowerment and Resistance in the Garden. Journal of Leisure Research, 39 (3), pp. 459-476.

Raby, R. (2005) What is resistance? Journal of Youth Studies, 8 (2), pp. 151-171.

Radway, J. (1991) Reading the Romance: Women, Patriarchy, and Popular Literature. Chapel Hill, NC: University of North Carolina Press.

Rose, M. (2002) The seductions of resistance: Power, politics, and a performative style of systems. Environment and Planning D: Society and Space, 20, pp. 383-400.

Roster, C. (2007) "Girl Power" and Participation in Macho Recreation: The Case of Female Harley Riders. Leisure Sciences, 29 (5), pp. 443-461.

Routledge, P. (1997) The Imagineering of Resistance: Pollok Free State and the Practice of Postmodern Politics. Transactions of the Institute of British Geographers, 22 (3), pp. 359-376.

Scott, J. (1989) Everyday forms of resistance. The Copenhagen Journal of Asian Studies, 4 (89), pp. 33-62.

Sharp, J.P., Routledge, P., Philo, C., and Paddison, R. (2000) Entanglements of Power: Geographies of Domination/Resistance. New York, NY: Routledge.

Sharpe, E.K. (2008) Festivals and social change: Intersections of pleasure and politics at a community music festival. Leisure Sciences, 30 (3), pp. 217-234.

Shaw, S. M. (2001) Conceptualizing resistance: Women's leisure as political practice. Journal of Leisure Research, 33 (2), pp. 186-202. 
Sotiropoulos, G. (2013) “Here and nowhere": Poststructuralism, resistance, and utopia. In: Dillet, B., MacKenzie, I., and Porter, R. eds. The Edinburgh Companion to Poststruturalism. Edinburgh: Edinburgh University Press, pp. 385-407.

Taylor, D. (2009) Normativity and normalization. Foucault Studies, 7, pp. 45-63.

Vinthagen, S. and Lilja, M. (2007) Resistance. In: Andersson, G.L. and Herr, K.G. eds. Encyclopedia of Activism and Social Justice. London: Sage.

Wallace, C., and Alt, R. (2001) Youth cultures under authoritarian regimes: The case of the swings against the Nazis. Youth and Society, 32 (3), pp. 275-302.

Wearing, B. (1998) Leisure and feminist theory. London: Sage.

Weitz, R. (2001) Women and their hair: Seeking power through resistance and accommodation. Gender and Society, 15, pp. 667-686. 